\title{
DETERMINANTS OF FOREIGN DIRECT INVESTMENT IN THE VISEGRAD GROUP COUNTRIES AFTER THE EU ENLARGEMENT
}

\author{
Weihua SU${ }^{1}$, Dongcai ZHANG ${ }^{1}$, Chonghui $\mathrm{ZHANG}^{1^{*}}$, Josef ABRHÁM ${ }^{2}$, \\ Mihaela SIMIONESCU ${ }^{3}$, Natalya YAROSHEVICH ${ }^{4}$, Valentina GUSEVA ${ }^{5}$ \\ ${ }^{1}$ College of Statistics and Mathematics, Zhejiang Gongshang University, Hangzhou 310018, China \\ ${ }^{2}$ Department of Legal Specializations and Public Administration, Metropolitan University Prague, \\ Dubečská 900/10, 10031 Prague, Czech Republic \\ ${ }^{3}$ Institute for Economic Forecasting of the Romanian Academy, Casa Academiei, Calea 13, \\ Septembrie nr. 13, sector 5, 050711, Bucharest, Romania \\ ${ }^{4}$ Department of Corporate Economics, Ural State University of Economics, 62, \\ Vos'mogo marta Str., 620144, Ekaterinburg, Russian Federation \\ ${ }^{5}$ Department of Business Informatics and Mathematics, \\ Tyumen Industrial University, Volodarskogo str. 38, 625000, Tyumen, Russian Federation
}

Received 18 March 2018; accepted 10 June 2018

\begin{abstract}
Considering the role of foreign direct investment (FDI) inflows in the sustainable development of a country, the main aim of this paper is to identify some macroeconomic factors that positively or negatively influence FDI in Visegrad group countries after the European Union (EU) enlargement in 2004. We employed two types of approaches in our analysis: i) time series and ii) panel data approach. According to the generalized ridge regressions estimated in Bayesian framework, the perceived corruption was a factor that influenced FDI in all the countries. In Poland, Czech Republic and Slovakia corruption came through as a serious obstacle for FDIs since 2005, but this was not the case for Hungary. Even if Hungary is perceived as a country with high influence, foreign investors seem no to care about this fact and are more interested in the quality of human resources and the possibility to increase exports. Our panel approach based on a panel ARDL model identified a significant relationship between FDI, corruption index and labour force with advanced education however this causality was only detected in the long run. According to the Granger causality in panel, the attraction of FDI inflows succeeded in generating changes in total tax rate, but the issues related to corruption were not reduced at an acceptable level for foreign investors in Poland, Slovakia, and the Czech Republic.
\end{abstract}

Keywords: foreign direct investments, V4 countries, perceived corruption index, ridge regression, panel ARDL model.

JEL Classification: C51, C53, E22.

${ }^{\star}$ Corresponding author. E-mail: zhangch1988@zjgsu.edu.cn

This is an Open Access article distributed under the terms of the Creative Commons Attribution License (http://creativecommons. org/licenses/by/4.0/), which permits unrestricted use, distribution, and reproduction in any medium, provided the original author and source are credited. 


\section{Introduction}

After the collapse of the Socialism and the planning system in the beginning of the 1990s, the countries of Central and Eastern Europe (CEECs) developed various strategies to attract foreign investment in order to achieve a sustained economic growth (Chidlow, Salciuviene, \& Young, 2009; Chen, Cheng, Nikic, \& Song, 2018; Qi \& Li, 2017). The foreign direct investments (FDI) brought by multinational corporations (MNCs) had an important role in the process of transformation of planned economies into functional market economies, due to the inflow of jobs, management skills, technological transfer together with increasing exports.

A large amount of empirical literature examined the factors that determine FDI to the Central and Eastern European countries, among them a factor of belonging to the Visegrad Group countries (see e.g. Abrhám, Strielkowski, Vošta, \& Šlajs, 2015a). There are more reasons for this tendency. First of all, since the middle of 1990s, a large number of investors, mostly from Western Europe, have chosen these states as host for their investment. Poland is the leader among these countries, being followed by Czech Republic and Hungary. A second reason is related to the fact that FDI is a significant source of external finance in the capital formation and ensures transfer of human capital, resources and technological progress between countries that generate economic and social development in the transition economies. Lastly, the liberalization towards a regime based on market depends on the changing nature of FDI (Stack, Ravishankar, \& Pentecost, 2017).

\section{Determinants and allocations of FDI}

There is a plethora of theories, concepts and models in literature that attempts to explain the FDI allocation. Kilic, Bayar, and Arica (2014) identified three groups of theories that explain FDI: micro-level theories, macro-level ones and development theories that combine macro and micro-level theories. There is no single theory that explains FDI. Microeconomic theories express the perspective of multinational enterprises (MNEs) trying to explain why these companies choose FDI rather than licensing or exporting (oligopolistic market theory, eclectic theory, company specific advantage theory, theory of internalization). Macroeconomic theories consider FDI as a type of capital flow between various economies and world in order to explain reasons and determinants of FDI (exchange rate theory, gravity approach, dynamic macroeconomic theory, economic geography, capital market theory, institutional analysis). Development theories consist of product life cycle theory, Japanese FDI theories and the five-stage theory of Dunning (1980), just to name a few. Other approaches, including various methods of multi criteria decision analysis and evaluation, such as the MCDA or MAGDM approaches, for example, can also be used (Hajiagha, Mahdiraji, Hashemi, \& Zavadskas, 2015; Hashemkhani Zolfani, Maknoon, \& Zavadskas, 2016; Ghorabaee, Amiri, Zavadskas, Hooshmand, \& Antuchevičienè, 2017; Zeng, Streimikiene, \& Baležentis, 2017; Zeng, Mu, \& Balezentis, 2018; Zeng, 2017; Rostamzadeh, Esmaeili, Nia, Saparauskas, \& Ghorabaee, 2017; Zhou, Su, Baležentis, \& Streimikiene, 2018). The use of the frontier techniques can also be applied in this case (Song, Fisher, Wang, \& Cui, 2018a; Song, Peng, Wang, \& Dong, 2018b; Song \& Wang, 2018). 
From the macroeconomic perspective, the determinants of FDI hold a central position. They can be identified in connection with the main theories. According to capital market theory, FDI is determined by interest rates. The basic reason for FDI and portfolio investment is the expectation for a higher rate of return than in the origin country. Moreover, the expected profit rate should compensate the risks and costs related to the business location and foreign currency. The limits of this theory were observed by Hymer (1976) who showed that there should be other factors than location to explain FDI. Moreover, Caves (1996) showed that the international difference in expected returns is not enough to generate FDI.

Dynamic macroeconomic FDI theory explains the flows of FDI by the changes in the macroeconomic environment. The connection between FDI and exchange rate is made by exchange rate theory in which FDI is perceived as a possibility of exchange rate reduction (Fernando, Hosseini, Zavadskas, Perera, \& Rameezdeen, 2017). The Porter's economic geography theory looks for success factors in a certain region where industries operate (Porter, 1990). The distribution of FDI according to spatial, cultural or economic distance is the central part of gravity approach (Isard, 1954). The impact of institutional framework on FDI is analyzed in the institutional theory of FDI (Wilhelms \& Witter, 1998). Some of these approaches include complicated decision-making, such as described by Stanujkic and Zavadskas (2015).

The eclectic theory of Dunning (1980) identifies four main categories of FDI investors: market seekers, resource seekers, efficiency seekers and strategic capabilities or asset seekers. The recent advances in reasons for FDI location identify four motives: efficiency-seeking FDI (vertical FDI), market-seeking FDI (horizontal FDI), complex FDI and export-platform FDI (Shepotylo, 2012).

Considering the important role of FDI in the economic and social development of the V4 countries, this paper identifies some macroeconomic determinants of FDI inflows into these economies. The description of common characteristics of these states will help them in designing the best FDI strategies to attract more foreign capital.

\section{Literature review}

The list of possible determinants of FDI is very large and it is difficult to get a global image of all the studies. Among the most popular determinants are infrastructure, the size of market and taxes and tariffs (Wach \& Wojciechowski, 2016), labor costs, exchange rate, unemployment rate, trade openness (Boateng, Hua, Nisar, \& Wu, 2015).

The traditional determinants employed by Botrić and Škuflić (2006) for host country are related to resources (skilled labour resources, business environment, infrastructure, natural resources), efficiency (trade costs, labour and production factors), and market seeking (market size, market potential, GDP per capita and economic growth).

Other factors like corruption or governance are less investigated (Subasat \& Bellos, 2013; Č́belková, Abrhám, \& Strielkowski, 2015). Most of the determinants were empirically tested, but only on particular regions or countries and in certain periods.

There are several common determinants of FDI in the CEECs: the presence of free trade areas and openness, advantages regarding market and efficiency (Merlevede \& Schoors, 2009). However, there are many determinants that are specific to some countries, being re- 
lated to location, quality of human capital and the evolution of some macroeconomic indicators (Demekas, Horvath, Ribakova, \& Wu, 2005).

The empirical evidences showed that transitional variables like progress in privatization, national risk in the host economy, trade liberalization, implemented reforms in banking sector had a strong impact on FDI in the CEECs (Brada, Kutan, \& Yigit, 2006).

The determinants of FDI from Western countries to CEECs in the period 1994-2000 were investigated by Bevan and Estrin (2004) using random effect models. The relevant factors that attracted FDI in this period were: gravity factors, unit labour costs in the host economy, proximity and market size. Labour costs were also identified by Janicki and Wunnava (2004) as factors that attracted FDI in 1997 from EU-15 to the CEECs that were later integrated in the EU: Romania, Bulgaria, Estonia, Czech Republic, Poland, Hungary, Slovenia and Slovakia. Moreover, the authors also identified other relevant drivers of FDI: the risk and the size of host economy and openness to trade.

The FDI from 10 Western European countries to EU-10 were explained by Stack, Ravishankar, and Pentecost (2017) for the period 1996-2007. The estimations based on a knowledge capital model suggested that for horizontal FDI similar countries characteristics in terms of income, size and factor endowments and trade costs are important determinants of FDI.

Wach and Wojciechowski (2016) identified the factors that attract FDI from EU-15 in the Visegrad Group countries in the period 2000-2012. The foreign investors in these states were interested in the host market potential reflected by GDP and in the short distance between the origin place and the chosen country. Contrary to the results obtained before by Gorynia, Nowak, Howak, and Wolniak (2007), these investors are not anymore efficiency-seekers.

Moreover, the location perspective was improved by Avioutskii and Tensaout (2016) who added the political element in choosing the location. For some CEE countries (Romania, Poland, Bulgaria, Czech Republic and Slovak Republic), the authors showed, using a panel data approach, that ideology influences the selection of a location for FDI. Factors like political risk, economic reforms and liberalization are significant drivers of FDI in these countries. Determinants of FDI like labour cost, market size and trade liberalization were also identified by Günther and Kristalova (2016) in the period 1994-2013 for CEECs that became EU members.

Most of the studies focusing on FDI determinants in the CEECs analyzed them from the perspective of transition process, but few studies identified the factors affecting FDI during the global crisis (Sakali, 2013; Jimborean \& Kelber, 2017).

The economic crisis from 2007 and 2011 were also taken into account when analyzing the FDI determinants in the CEECs in the period 1993-2014. In this context, using a panel data general to particular approach, Jimborean and Kelber (2017) identified domestic determinants (human resources, competitiveness, past FDI, infrastructure, trade openness, risk premium, corporate tax system, market dimension, progress in achieving structural reforms, spatial proximity to Western Europe, EU membership) and external ones (global economic conditions and risk environment, financial and macroeconomic conditions the euro area).

Some of the studies focused on the determinants of FDI in a certain region or country at sectoral level to highlight that there are differences in attracting FDI according to the sector 
of activity. Resmini (2000) analyzed the determinants of the FDI from EU to CEECs before 2000 (1986-1997) at sectoral level. The study focused on manufacturing sectors and the estimations based on a fixed-effect model indicated heterogeneity at sectoral level in attracting FDI. The progress towards a market economy had a significant impact on the FDI sent in CEECs. Wage differentials attracted FDI only in science-based sectors and scale-intensive sectors. In traditional sectors, the determinants of FDI were: the opportunity to exploit the agglomeration economies and the economy's degree of openness. However, these conclusions are valid for the period before countries' integration in the EU. For food industry in Poland with 12 branches, Walkenhorst (2001) identified some determinants of FDI in the period 1991-1997: value-added, privatization speed, company size and import share. A sectoral approach for the determinants of FDI in manufacturing industry was applied for Czech Republic by Michalíkova and Galeotti (2010) who built panel data models for 23 sectors of manufacturing industry over the period 2000-2007. The empirical results indicated that abundance of human capital with technical skill represents a comparative advantage in the Czech Republic. The foreign investors were attracted by those sectors with high educated labour resources. The tendency is to invest in sectors with high energy requirements. Relative unit labour costs are also important for foreign investors when deciding to invest in Czech Republic. The foreign investment in the manufacturing industry from Hungary might be explained by location of the country in Europe (Hlavacek \& Bal-Domanska, 2016). In the case of Slovakia, M. Grančay and N. Grančay (2017) showed that foreign investors followed those industries and sectors with higher capital intensity of production and higher added value.

"Special economic areas" with services and infrastructures accessible on preferential basis and low rates of taxation from Poland, Czech Republic and Hungary attracted more FDI compared to those areas that are not considered special in the period 1994-2001 (Guagliano \& Riela, 2005). For Hungary, considered that the main factors that explain the FDI attraction are: privatization policy and the relative liberal laws on FDI (Hlavacek \& Bal-Domanska, 2016).

The EU membership offers multiple advantages for V4 countries, among them being: access to EU funds, almost unlimited access to the EU markets, non-VAT trading inside the EU, stable legal environment, less regulated migration of labour force, lower costs of operations due to higher concurrence and efforts of liberalization of different markets, improvement regarding transport corridors.

Poland ranks the first among V4 countries according to the distance to frontier score, being ranked as the $24^{\text {th }}$ out of 190 states in the report "Doing Business 2017" published by World Bank (2017). Even if the Czech Republic is ranked on the $24^{\text {th }}$ place, it is the first country as per capita inflows and FDI stock in 2016. Abrhám, Bilan, Krauchenia, and Strielkowski (2015b) note the advantages of the Czech labour market with the other Eastern European countries. The performance is due to some important advantages of the Czech Republic:

- location of the country in Europe (it is placed in the heart of Europe);

- investment incentives;

- well-skilled and cheap labour force;

- strong stability of currency;

- independence and power of central bank;

- fast economic growth; 
- rapid increase in the FDI since 2012;

- state policy in favor of Euro zone accession.

Czech government proposed an investment incentive plan to attract greenfield, but also to develop the existent structures. The plan includes several measures:

- equal and non-discriminant treatment of foreign investors;

- protection for property rights and the freedom to export profits;

- avoidance of double taxation and investment protection;

- improved services for foreign investors and intense activity abroad;

- improvement of communication, development and research.

Moreover, the "Welcome Package for Investors" makes the immigration faster for people who need residence and job in the Czech Republic.

Hungary is also an attractive country for foreign investment due to some key points:

- location of the country in Europe (gateway to Central and Southeast Europe);

- well-skilled and high educated labour force, especially in medicine, economics and engineering;

- fast-growing economy;

- most well-developed financial system in the entire region;

- good infrastructure and is still developed using EU funds;

- significant supply chain opportunities in electronic and automotive industries;

- direct support through 2014-2010 National Development Plan for infrastructure, tourism, environmental protection and healthcare;

- economic and political stability induced by the integration in the EU and by the support of international organizations.

Hungarian Government established an agency called Hungarian Investment Promotion Agency to support the foreign investors. In the context of global economic crisis, Hungary took measures to maintain the foreign investors: special guarantee programs and loans, creation of a better administrative situation with lower formalities to encourage acquisition of buildings.

There are some particular advantages for foreign investors that choose Slovak Republic as host country:

- location of the country in Europe (it is placed in the centre of Europe);

- well-skilled and cheap labour force;

- advantageous tax system;

- some financial aid forms for promoting FDI;

- low tax rate;

- use of Euro as national currency since 2009;

- large potential of growth;

- lower cost of living compared to other countries from Europe.

The ability of Poland to attract FDI is justified by some strong points:

- location of the country in Europe (in the centre of Europe);

- well-skilled, cheap and multilingual labour force;

- fast-growing economy;

- ability to manage recent crisis better than other CEE countries;

- government measures to encourage FDI. 
Polish Government provided support to foreign investors in order to improve the country's attractiveness. For example, in April 2002, a law was passed by Parliament and stipulated that Government should give assistance to manager access to EU structural funds, investment assistance in Special Economic Zones, creation of technological and industrial regions for more companies working in the same sector. A firm is registered as limited liability company in only 24 hours in Poland since 2012. A stabilization and development plan was formulated by Polish Government to grant credits to medium and small sized firms that invest in renewable energy sources. The Poland's bureaucracy was diminished with the adoption of an Act Limiting Administrative Barriers for Citizens and Businesses in July 2011.

The tendencies observed for the entire region of CEE countries and V4 countries were also observed in Poland, the country that attracted the most FDI. Most of the studies treating the determinants of FDI in CEECs focused on Poland. In this country, the foreign investors are both efficiency and market seekers (Gorynia et al., 2007). Location determinants were identified for FDI inflow into Poland using data based on a survey that uses online questionnaire. Based on these data collected in February 2005 and a multinomial logit model, Chidlow et al. (2009) showed that agglomeration factors and knowledge-seeking factors alongside market are the main FDI determinants for Mazowieckie region that includes the capital. For the rest of the Polish regions, geographical factors and efficiency are the main drivers of FDI. In a recent study, Nazarczuk and Krajewska (2017) showed the importance of geographical factors and structural characteristics in attracting FDI in Polish districts in the period 2011-2015. Using negative binomial regression models, the authors showed that FDI was mostly located in Polish districts near large urban centers with high economic and social development reflected in the quality of human resources, access on labor market and infrastructure. The location is also appreciated by Portuguese investors in Poland (Aleksandruk \& Forte, 2016), but it is not the key factor. The surveys among Portuguese investors in Poland showed that large domestic market is the most important determinant of FDI. However, there are also many barriers in locating FDI in Poland, as Portuguese managers indicated: bureaucracy, language obstacles and cultural differences.

Cieślik (2007) and Cieślik, Michałek, and Mycielski (2016) used negative binomial regression models to explain the FDI inflow from EU-15 to Poland in the period 1989-2014. The market size and the differences in factor endowments explained the orientation of the managers from EU-15 towards Poland.

\section{Methodology}

The methodological framework is conditioned by the analysis made on two types of data: time series for the individual analysis of economic phenomenon in each country and panel data for simultaneous analysis of all countries in the sample in the same period. Given the short period of analysis, the time series approach is based on Bayesian methods that eliminate the deficiency of a short sample. Moreover, panel data approach also solves the issue of short period. The factors that influence FDI will be identified using different regression models (generalized ridge regression models under Bayesian framework and panel autoregressive-distributed lag models). The analysis is enriched by considering a principal component 
analysis based on Bayesian estimations and panel Granger causality test to check if there are significant causes of FDI among explanatory variables.

Considering the time series approach, the traditional regression models in frequentist Econometrics might generate misleading results when using empirical data. This issue is encountered when the method assumptions are not fulfilled. Therefore, the regression model should describe all the possible patterns in data. This disadvantage is not met when a Bayesian nonparametric approach is used since it comes with flexible models presented as an infinite mixture of regressions with minimum assumptions related to data.

The ridge regression linear model provides estimates via shrinkage and it reduces the forecast error and the mean squared error.

For a dataset $D_{n}=(X, y)$ with $X=\left(x_{i p}\right)_{n x p}$ and $y=\left(y_{1}, \ldots, y_{n}\right)^{T}$ and a conjugate normal-inverse gamma prior density to $\left(\beta, \sigma^{2}\right)$, we have:

$$
\begin{gathered}
f\left(y \mid X, \beta, \sigma^{2}\right)=n_{n}\left(y \mid X \beta, \sigma^{2} I_{n}\right)=\prod_{i=1}^{n} n\left(y \mid x_{i}^{T} \beta, \sigma^{2}\right) \text { and } \\
\pi\left(\beta, \sigma^{2}\right)=n_{p}\left(\beta \mid m, \sigma^{2} V\right) i g\left(\sigma^{2} \mid a, b\right)=n i g\left(\beta, \sigma^{2} \mid m, V, a, b\right),
\end{gathered}
$$

where $n_{n}(. \mid \mu, \Sigma)$ is probability density function (pdf) associated to a $n$-variate normal distribution, $n\left(. \mid \mu, \sigma^{2}\right)$ is probability density function associated to a univariate normal distribution and $\operatorname{ig}(. \mid a, b)$ is probability density function associated to an inverse gamma distribution (where $a$ is the shape parameter, $b$ is rate parameter and $\frac{1}{b}$ is a scale parameter), $n i g\left(\beta, \sigma^{2} \mid m, V, a, b\right)$ - probability density function (pdf) associated to a NIG distribution (product of two pdfs for inverse-gamma distribution and multivariate normal one, as in Lindley and Smith (1972).

Under the assumption that joint prior distribution of $\left(\beta, \sigma^{2}\right)$ follows a NIG distribution, according to marginal approach, $\beta$ has a Student prior distribution with parameters: mean $m$ and covariance matrix $V 1(\beta)=\frac{b}{a-1} V$ with 2 a degrees of freedom. $\sigma^{2}$ follows an inverse-gamma prior distribution with average $\frac{b}{a-1}$ and variance $\frac{b^{2}}{(a-1)^{2}(a-2)}$.

The ridge regression model ( $\mathrm{RR}$ model) is defined as a Bayesian linear regression model with normal prior distribution $n_{p}\left(\beta \mid 0, \sigma^{2} \lambda^{-1} I_{p}\right)$ for $\beta$, conditionally on $\sigma^{2}$. In case $\left(\beta, \sigma^{2}\right)$ follows a prior normal inverse-gamma distribution $\operatorname{nig}\left(\beta, \sigma^{2} \mid 0, \lambda^{-1} I_{p}, a, b\right)$, inferential procedures for the Bayesian normal linear regression model are employed for ridge regression (Karabatsos, 2014).

For the design matrix $X$, the singular value decomposition (svd) is $X=U D W^{T}$. In this case, $\mathrm{U}$ and $\mathrm{W}$ represent orthogonal matrices of $n \times q$, respectively $p \times q$, where $q=\min (n, p)$ and $Z=U D=X W$.

$D=\operatorname{diag}\left(d_{1}, \ldots, d_{q}\right)$ represents a diagonal matrix of singular values $d_{1}>d_{2}>\ldots>d_{q}>0$ $\left(d_{1}^{2}, \ldots, d_{q}^{2}\right)$ provides at most the first q eigenvalues ( $\mathrm{q}$ different from 0 , of $X^{T} X$ and shows the diagonal values of $Z^{T} Z$.

The $q$ principal components associated to $X$ are placed in the columns of $X W$. The eigenvalues $\left(d_{1}^{2}, \ldots, d_{q}^{2}\right)$ are the column-wise sum of squares over the rows. 
In our empirical analysis, we will consider:

$$
y_{i} \mid X_{i} \sim f\left(y \mid X_{i}\right), i=1,2, \ldots, n,
$$

where: $f(y \mid X) \sim N\left(y \mid X^{\prime} \beta, \sigma^{2}\right) ; \beta \mid \sigma^{2} \sim N\left(0, \sigma^{2} \cdot \frac{1}{\hat{\lambda}} \cdot I_{p}\right) ; \sigma^{2} \sim I G(\varepsilon, \varepsilon)$ (inverse Gamma distribution); $\lambda$ - penalty; $\hat{\lambda}$ - Marginal Maximum Likelihood Estimate of $\lambda$; $y$ is centered in order to get a null mean and the explanatory variables are rescaled to get a null mean and a variance equal to $1 ; \beta$ - standardized coefficients (posterior mean) based on zero-mean centered $y$ and rescaled explanatory variables; $b$ - column vector based on $\beta$ :

$$
b=\left[\operatorname{mean}(y)-\frac{\operatorname{mean}(X) \cdot \beta}{S D(X)^{\prime}}\right] \frac{\beta}{S D(X)} .
$$

The first entry of $b$ is the intercept and the rest ones are the slopes.

mean $(X)$ - row vector for covariate means; $S D(X)^{\prime}$ - column vector with covariate standard deviations.

If $y$ is a vector of $z$-scores with null mean and variance $1, \beta$ contain the coefficients on correlation scale. $\beta$ ranges only between -1 and 1 , when the predictors are not correlated.

The significant predictors that explain y are selected using PP1SD indicator that represents the posterior probability for the standardized coefficient to be within 1 standard deviation from 0 .

The panel data analysis is focused on the technique known as Pooled Mean

Group (PMG) used by Pesaran, Shin, and Smith (1999) to construct nonstationary dynamic panels. The model based on PMG estimation has the following general form:

$$
Y_{i t}=\sum_{j=1}^{p} \lambda_{i j} y_{i, t-j}+\sum_{j=0}^{q} \delta_{i j} X_{i, t-j}+\mu_{i}+\varepsilon_{i t}
$$

where: $i$ is the index for cross-sections taking values from 1 to $\mathrm{N} ; t$ is the index for time taking values from 1 to $\mathrm{T} ; X_{i t}$ - vector of $\mathrm{K} \mathrm{x} 1$ regressors; $\lambda_{i j}$ - scalar; $\mu_{i}$ - specific effect of group.

When the variables are co-integrated and integrated of order 1 , the error term has a stationary data series. The cointegrated variables have the capacity to rejoinder to a deviation from the long-term equilibrium.

The above equation is reparametrized into error correction equation:

$$
\Delta Y_{i t}=\varphi_{i} y_{i, t-j}-\theta_{i} X_{i, t-j} \sum_{j=1}^{p-1} \lambda_{i j} \Delta y_{i, t-j}+\sum_{j=0}^{q-1} \delta_{i j} \Delta X_{i, t-j}+\mu_{i}+\varepsilon_{i t},
$$

where $\varphi_{i}$ - error correction coefficient indicating the adjustment speed.

In case $\varphi_{i}=0$, there is not any long-run relationship between variables. If $\varphi_{i}$ is statistically significant and negative, there is a long-run relationship between variables.

Granger Causality is based on bivariate regressions and the analysis on panel data uses more approaches. The bivariate regressions using panel data and $y$ and $x$ as variables have the following form, where $t$ shows time series dimension and $i$ the cross-sectional size:

$$
\begin{aligned}
& y_{i, t}=\alpha_{0, i}+\alpha_{1, i} y_{i, t-1}+\ldots+\alpha_{l, i} y_{i, t-1}+\beta_{1, i} x_{i, t-1}+\ldots+\beta_{l, i} x_{i, t-1}+e_{i, t} ; \\
& x_{i, t}=\alpha_{0, i}+\alpha_{1, i} x_{i, t-1}+\ldots+\alpha_{l, i} x_{i, t-1}+\beta_{1, i} y_{i, t-1}+\ldots+\beta_{l, i} y_{i, t-1}+e_{i, t},
\end{aligned}
$$

where $e$ denotes the error term. 
The panel causality tests depend on the assumptions about coefficients homogeneity across cross-sections. In this paper, we will employ the approach that considers panel data as a large stacked set of data. The Granger Causality test in standard way is conducted, but not allowing data from one cross-section enter the lagged values from the next cross-section. According to this method, there are the same coefficients across the cross-sections for any $i$ and $j$ :

$$
\begin{aligned}
\alpha_{0, i} & =\alpha_{0, j} ; \\
\alpha_{1, i} & =\alpha_{1, j} ; \\
& \ldots \\
\alpha_{l, i} & =\alpha_{l, j} ; \\
\beta_{0, i} & =\beta_{0, j} ; \\
\beta_{1, i} & =\beta_{1, j} ; \\
& \ldots \\
\beta_{l, i} & =\beta_{l, j} ;
\end{aligned}
$$

There is another approach proposed by Dumitrescu and Hurlin (2012) that allows the coefficients to vary across cross-sections, but the small set of data used in our empirical analysis does not permit us to consider this approach.

\section{FDI determinants in V4 countries. Empirical analysis}

More factors that affect FDI inflows in the V4 countries (Poland, Hungary, Czech Republic, and Slovakia) and they will be empirically tested in the period 2005-2016. All these countries entered the EU in 2004 and we selected a period after this moment. The variables that were taken into consideration are:

- Foreign direct investment (FDI) net inflows: net inflows of investment in order to have a lasting management interest in a firm (a minimum of $10 \%$ of voting stock) when this firm is located in another country compared to investor's one. It includes: short-run capital in balance of payments, earnings' reinvestment, equity capital plus another long-run capital.

- GDP per capita growth (\%);

- Poverty headcount ratio at \$ 1.90 a day (2011 PPP) (\% of population);

- Cost of business start-up procedures (\% of GNI per capita);

- Corruption Perceptions Index provided by Transparency International: an aggregate index showing the opinion regarding the level of corruption in the public sector of a state;

- Exports of goods and services (\% of GDP);

- Real wage $(2010=100)$;

- Total tax rate (\% of commercial profits);

- Real effective exchange rate $(2010=100$ for the index $)$;

- Broad money (\% of GDP);

- Youth unemployment rate (\% of total labor force ages 15-24) (modeled ILO estimate);

- Unemployment rate (\% of total labor force) (modeled ILO estimate);

- Time required to start a business (days); 
- Labor force having advanced education (\% of total working-age population having advanced education);

- Inflation rate based on harmonized index of prices from Eurostat.

Except for inflation and corruption index, the data sets for all the other variables are provided by World Bank.

In Figure 1, the evolution of FDI net inflows in V4 countries between 2005 and 2016 is described. From the very beginning, we observe that Hungary FDI is an outlier compared to the values of FDI from the other countries. The maximum level of FDI net inflows in Hungary was achieved in 2007, before the world economic crisis start (around 51\% from GDP). A sudden fall was observed since then till a minimum in 2000. At the end of the period the values of the indicator became rather close. Considering the particular evolution of FDI net inflows in Hungary compared to the other V4 countries, a separate analysis will be provided when the panel data will be described.

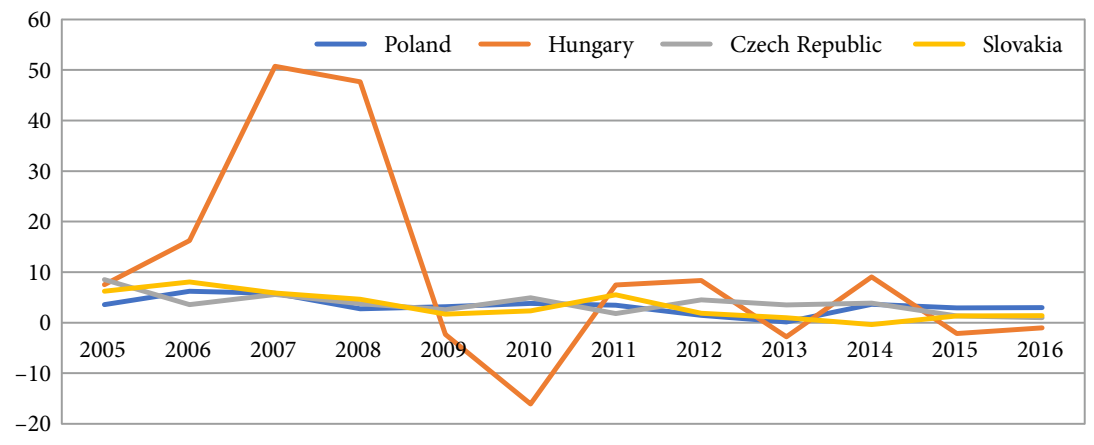

Figure 1. FDI net inflows in V4 countries (\% of GDP) (source: own results)

Levin-Lin-Chu test was used to check for the existence of unit roots in the panel data. According to this test, the panel data for FDI, time required to start a business, GDP per capita growth, poverty headcount ratio at $\$ 1.90$ a day, cost of business start-up procedures, total unemployment rate and tax rate were stationary at $5 \%$ level of significance.

The data series for exports of goods and services, real effective exchange rate $(2010=$ $100)$, board money, youth unemployment rate, wage, inflation rate, labour force with advanced education, and corruption perceptions index were not stationary in level at $5 \%$ level of significance and we computed the data series in first difference to achieve stationary data. Therefore, new variables will be constructed as absolute change of these indicators, excepting broad money for which we computed rate of board money.

According to generalized ridge regression model for Poland, the following variables had a significant impact on FDI inflows in Poland in the period 2005-2016:

- GDP per capita growth;

- Total tax rate;

- Inflation rate;

- Corruption index;

- Poverty headcount ratio at $\$ 1.90$ a day. 
GDP per capita growth had a positive impact on FDI net inflows in Poland after 2004 showing that the foreign investors were directly interested on the country's standard of life (Table 1). As expected, the increases in inflation rate and corruption had a negative effect on FDI inflows in Poland in the period 2005-2016. Contrary to expectations, even if the total tax rate and poverty headcount ration increased, the foreign investors continued to come in Poland. Our results are consistent with the conclusion of Amarandei (2013) that showed a negative impact of corruption on FDI in 10 CEE countries (Poland, Hungary, Bulgaria, Estonia, Lithuania, Latvia, Romania, Czech Republic, Slovakia and Slovenia), but the intensity of the relationship FDI-corruption is less than expected. Moreover, Poland made constant improvements in corruption.

According to principal component analysis based on a Bayesian procedure (Table 2), in Poland the most relevant determinants (corruption index and poverty headcount ratio at $\$ 1.90$ a day) had a negative influence on FDI and could be seen as a component reflecting social issues of Poland.

GDP per capita growth and exports of goods and services had a positive impact on FDI net inflows in Hungary after 2004 showing that the foreign investors were directly interested on the country's standard of life and perspectives on exports (Table 3). Contrary to expectations, the increases in inflation rate, tax rate, cost of business start-up procedures, wage and corruption had attracted FDI inflows in Hungary in the period 2005-2016. Even if the unemployment rate and labor force with advanced education increased, the FDI decreased. Foreign investors in Hungary seemed to be sensitive to poverty issues. The correlation between corruption and FDI is contrary to the result of Smarzynska and Wei (2000) based on microeconomic data and in line with the result of Bellos and Subasat (2012) that showed that corruption did not discourage FDI in developing countries using a gravity panel data approach. However, since then, Hungary made progresses in terms of corruption reduction.

In Hungary, more macroeconomic variables had a significant impact on FDI in the period 2005-2016, after country's integration in the EU:

- Exports of goods and services;

- Cost of business start-up procedures;

- Total tax rate;

- Inflation rate;

- Real effective exchange rate index;

- Broad money;

- Youth unemployment rate;

- Total unemployment rate;

- Wage;

- Labor force with advanced education;

- Poverty headcount ratio at $\$ 1.90$ a day.

According to principal analysis, the most important component that includes poverty and inflation rate had a negative impact on FDI (Table 4 ). The high poverty and inflation rate did not attract foreign investors in Hungary. This component might reflect the social instability. 
Table 1. Marginal Posterior Summary Estimates for generalized ridge regression in case of Poland (source: own results)

\begin{tabular}{|l|c|c|c|c|}
\hline \multicolumn{1}{|c|}{ Covariate } & Beta & Standard deviation & PP1SD & b \\
\hline Intercept & 0 & 0 & 1 & 6.053 \\
\hline GDP per capita growth & 0.67 & 0.284 & $\mathbf{0 . 0 9 7}$ & 0.406 \\
\hline Exports of goods and services & 0.013 & 0.218 & 0.662 & 0.003 \\
\hline Cost of business start-up procedures & -0.035 & 0.565 & 0.662 & -0.012 \\
\hline Total tax rate & 0.129 & 0.042 & $\mathbf{0 . 0 3 0}$ & 0.074 \\
\hline Inflation rate & -0.367 & 0.155 & $\mathbf{0 . 0 9 4}$ & -0.210 \\
\hline Corruption index & -0.149 & 0.035 & $\mathbf{0 . 0 0 4}$ & -0.015 \\
\hline Real effective exchange rate index & -0.006 & 0.059 & 0.66 & -0.001 \\
\hline Broad money & -0.088 & 0.234 & 0.631 & -0.013 \\
\hline Youth unemployment rate & -0.119 & 0.086 & $\mathbf{0 . 3 3 9}$ & -0.021 \\
\hline Time required to start a business & 0.145 & 0.264 & 0.596 & 0.031 \\
\hline Total unemployment rate & 0.040 & 0.255 & 0.657 & 0.013 \\
\hline Wage and salaried workers, total & 0.093 & 0.388 & 0.65 & 0.068 \\
\hline Labor force with advanced education & -0.062 & 0.192 & 0.639 & -0.145 \\
\hline Poverty headcount ratio at \$1.90 a day & 0.404 & 0.103 & $\mathbf{0 . 0 0 6}$ & 1.98 \\
\hline
\end{tabular}

Table 2. Posterior Estimates of Principal Components of explanatory variables in case of Poland (source: own results)

\begin{tabular}{|c|c|c|c|}
\hline Component & alpha & Eig. & lambda \\
\hline 1 & -0.235 & 101.573 & 26.525 \\
\hline 2 & 0.000 & 27.416 & 10000 \\
\hline 3 & 0.85 & 15.465 & 1.744 \\
\hline 4 & 0.000 & 9.45 & 10000 \\
\hline 5 & 0.000 & 7.083 & 10000 \\
\hline 6 & 0.000 & 4.822 & 10000 \\
\hline 7 & 0.000 & 1.345 & 10000 \\
\hline 8 & 0.000 & 0.598 & 10000 \\
\hline 9 & 0.000 & 0.201 & 10000 \\
\hline 10 & 0.255 & 0.037 & 1.160 \\
\hline 11 & 0.000 & 0.01 & 10000 \\
\hline 12 & 0.000 & 0.000 & 10000 \\
\hline
\end{tabular}


Table 3. Marginal posterior summary estimates for generalized ridge regression in case of Hungary (source: own results)

\begin{tabular}{|l|c|c|c|c|}
\hline \multicolumn{1}{|c|}{ Covariate } & Beta & Standard deviation & PP1SD & $\mathrm{b}$ \\
\hline Intercept & 0 & 0 & 1 & -103.075 \\
\hline GDP per capita growth & 0.23 & 0.238 & 0.661 & 0.075 \\
\hline Exports of goods and services & 1.057 & 1.041 & $\mathbf{0 . 4 6 1}$ & 0.126 \\
\hline Cost of business start-up procedures & 0.93 & 0.704 & $\mathbf{0 . 3 5 8}$ & 0.165 \\
\hline Total tax rate & 1.877 & 1.117 & $\mathbf{0 . 2 4 5}$ & 0.487 \\
\hline Inflation rate & 4.76 & 1.568 & $\mathbf{0 . 0 3 1}$ & 1.898 \\
\hline Corruption index & 1.719 & 2.62 & 0.57 & 0.647 \\
\hline Real effective exchange rate index & 2.589 & 1.209 & $\mathbf{0 . 1 3 4}$ & 0.528 \\
\hline Broad money & -1.782 & 0.688 & $\mathbf{0 . 0 6 7}$ & -0.477 \\
\hline Youth unemployment rate & -5.317 & 2.007 & $\mathbf{0 . 0 6 1}$ & -1.114 \\
\hline Time required to start a business & -0.413 & 0.633 & 0.571 & -0.032 \\
\hline Total unemployment rate & -4.401 & 1.738 & $\mathbf{0 . 0 7 4}$ & -2.205 \\
\hline Wage & 0.893 & 0.817 & $\mathbf{0 . 4 3 5}$ & 1.109 \\
\hline Labor force with advanced education & -0.851 & 0.864 & $\mathbf{0 . 4 7 1}$ & -0.473 \\
\hline Poverty headcount ratio at \$1.90 a day & -5.315 & 1.814 & $\mathbf{0 . 0 3 8}$ & -20.165 \\
\hline
\end{tabular}

Table 4. Posterior estimates of principal components of explanatory variables in case of Hungary (source: own results)

\begin{tabular}{|c|c|c|c|}
\hline Component & alpha & Eig. & lambda \\
\hline 1 & -1.203 & 71.984 & 99.315 \\
\hline 2 & 0.000 & 52.214 & 10000 \\
\hline 3 & -4.096 & 14.346 & 11.032 \\
\hline 4 & -9.694 & 13.413 & 2.2 \\
\hline 5 & -2.534 & 7.16 & 16.506 \\
\hline 6 & 0.000 & 5.378 & 10000 \\
\hline 7 & 0.000 & 2.056 & 10000 \\
\hline 8 & 0.000 & 0.774 & 10000 \\
\hline 9 & 0.000 & 0.483 & 10000 \\
\hline 10 & 0.255 & 0.156 & 10000 \\
\hline 11 & 0.000 & 0.036 & 10000 \\
\hline 12 & 0.000 & 0.000 & \\
\hline
\end{tabular}

In the Czech Republic, more macroeconomic variables had a significant impact on FDI in the period 2005-2016 (Table 5):

- Cost of business start-up procedures;

- Corruption index;

- Available money loans;

- Youth unemployment rate; 
- Labor force with advanced education;

- Time required to start a business.

The foreign investors in Czech Republic are not interested in aspects related to business start-up (costs and time to start a business) since the time and costs for beginning a business in this country are acceptable. Corruption issue seems to be an important criterion in deciding to locate a foreign company in Czech Republic. Our result is consistent with the conclusion of Castro and Nunes (2013) that showed a negative impact of corruption on FDI in Czech Republic and other CEE countries. Moreover, the increase in the labour force with advanced education attracted FDI in Czech Republic while the growth of youth unemployment rate did not encourage foreign investors to come in Czech Republic.

According to principal analysis, the most important component that includes Time required to start a business and Cost of business start-up procedures had a negative impact on FDI (Table 6). When costs and time increase, the foreign investor are less encouraged to invest in Czech Republic.

Table 5. Marginal posterior summary estimates for generalized ridge regression in case of Czech Republic (source: own results)

\begin{tabular}{|l|l|l|l|l|}
\hline Covariate & Beta & Standard deviation & PP1SD & b \\
\hline Intercept & 0 & 0 & 1 & -25.568 \\
\hline GDP per capita growth & -0.091 & 0.125 & 0.549 & -0.048 \\
\hline Exports of goods and services & 0.109 & 0.202 & 0.599 & 0.023 \\
\hline Cost of business start-up procedures & 0.582 & 0.301 & $\mathbf{0 . 1 7 7}$ & 0.721 \\
\hline Total tax rate & -0.067 & 0.198 & 0.637 & -0.065 \\
\hline Inflation rate & -0.001 & 0.051 & 0.663 & -0.001 \\
\hline Corruption index & -0.885 & 0.545 & $\mathbf{0 . 2 6 1}$ & -0.422 \\
\hline Real effective exchange rate index & -0.048 & 0.062 & 0.536 & -0.013 \\
\hline Broad money & 0.065 & 0.203 & 0.639 & 0.015 \\
\hline Youth unemployment rate & -0.385 & 0.31 & $\mathbf{0 . 3 8 4}$ & -0.186 \\
\hline Time required to start a business & 0.291 & 0.092 & $\mathbf{0 . 0 2 5}$ & 0.069 \\
\hline Total unemployment rate & -0.107 & 0.154 & 0.559 & -0.158 \\
\hline Wage and salaried workers, total & -0.187 & 0.247 & 0.542 & -0.388 \\
\hline Labor force with advanced education & 0.848 & 0.489 & $\mathbf{0 . 2 3}$ & 1.379 \\
\hline Poverty headcount ratio at \$1.90 a day & 0.033 & 0.124 & 0.646 & 1.92 \\
\hline
\end{tabular}

Table 6. Posterior estimates of principal components of explanatory variables in case of Czech Republic (source: own results)

\begin{tabular}{|c|c|c|c|}
\hline Component & alpha & Eig. & lambda \\
\hline 1 & -0.554 & 76.501 & 5.055 \\
\hline 2 & 0.000 & 43.465 & 10000 \\
\hline 3 & 0.000 & 26.219 & 10000 \\
\hline 4 & 0.000 & 9.905 & 10000 \\
\hline
\end{tabular}


End of Table 6

\begin{tabular}{|c|c|c|c|}
\hline Component & alpha & Eig. & lambda \\
\hline 5 & 0.000 & 5.885 & 10000 \\
\hline 6 & 0.000 & 3.204 & 10000 \\
\hline 7 & -0.023 & 1.528 & 100.944 \\
\hline 8 & -1.358 & 0.853 & 0.909 \\
\hline 9 & 0.000 & 0.278 & 10000 \\
\hline 10 & 0.000 & 0.111 & 10000 \\
\hline 11 & 0.000 & 0.050 & 10000 \\
\hline 12 & 0.000 & 0.000 & 10000 \\
\hline
\end{tabular}

In Slovakia, more macroeconomic variables had a significant impact on FDI in the period 2005-2016, after country's integration in the EU (Table 7):

- GDP per capita growth;

- Exports of goods and services;

- Total tax rate;

- Inflation rate;

- Corruption index;

- Youth unemployment rate;

- Time required to start a business;

- Labor force with advanced education;

- Poverty headcount ratio at $\$ 1.90$ a day.

GDP per capita growth had a positive impact on FDI inflows in Slovak Republic, but the increase in exports did not encouraged FDI, because exports level had not a satisfactory level compared to other countries in the region. The foreign investors in Slovakia look for human resources quality, but they are sensitive to poverty issues. They are not interested in aspects related to business start-up (costs and time to start a business) since the time and costs for beginning a business in this country are acceptable. Corruption issue seems to be an important criterion in deciding to locate a foreign company in Slovakia. Our result is consistent with the conclusion of Amarandei (2013) and Castro and Nunes (2013) that showed a negative impact of corruption on FDI in Slovakia and other CEE countries.

Table 7. Marginal posterior summary estimates for generalized ridge regression in case of Slovak Republic (source: own results)

\begin{tabular}{|l|c|c|c|c|}
\hline \multicolumn{1}{|c|}{ Covariate } & Beta & Standard deviation & PP1SD & b \\
\hline Intercept & 0 & 0 & 1 & -9.026 \\
\hline GDP per capita growth & 0.332 & 0.101 & $\mathbf{0 . 0 2}$ & 0.081 \\
\hline Exports of goods and services & -0.203 & 0.035 & $\mathbf{0 . 0 0 0}$ & -0.022 \\
\hline Cost of business start-up procedures & 0.344 & 0.062 & $\mathbf{0 . 0 0 0}$ & 0.247 \\
\hline Total tax rate & -0.310 & 0.062 & $\mathbf{0 . 0 0 1}$ & -0.259 \\
\hline Inflation rate & 0.209 & 0.041 & $\mathbf{0 . 0 0 1}$ & 0.116 \\
\hline Corruption index & -0.199 & 0.131 & $\mathbf{0 . 2 9 4}$ & -0.056 \\
\hline
\end{tabular}


End of Table 7

\begin{tabular}{|l|c|c|c|c|}
\hline \multicolumn{1}{|c|}{ Covariate } & Beta & Standard deviation & PP1SD & $\mathrm{b}$ \\
\hline Real effective exchange rate index & -0.026 & 0.106 & 0.649 & -0.005 \\
\hline Broad money & -0.131 & 0.164 & 0.531 & -0.0035 \\
\hline Youth unemployment rate & -0.155 & 0.079 & $\mathbf{0 . 1 7 1}$ & -0.033 \\
\hline Time required to start a business & 0.452 & 0.125 & $\mathbf{0 . 0 1 1}$ & 0.076 \\
\hline Total unemployment rate & -0.006 & 0.070 & 0.661 & -0.003 \\
\hline Wage and salaried workers, total & 0.284 & 0.070 & 0.6005 & 0.247 \\
\hline Labor force with advanced education & 0.342 & 0.058 & $\mathbf{0 . 0 0 0}$ & 0.124 \\
\hline Poverty headcount ratio at \$1.90 a day & -0.050 & 0.043 & $\mathbf{0 . 4 0 7}$ & -0.388 \\
\hline
\end{tabular}

The most relevant FDI determinants in Slovakia (exports, cost of business start-up procedures, labour force with advanced) could be summarized as a principal component that reflects aspects related to costs and resources in the host country (Table 8).

Table 8. Posterior estimates of principal components of explanatory variables in case of Slovak Republic (source: own results)

\begin{tabular}{|c|c|c|c|}
\hline Component & alpha & Eig. & lambda \\
\hline 1 & -0.899 & 71.503 & 1.728 \\
\hline 2 & 0.000 & 41.814 & 10000 \\
\hline 3 & 0.000 & 19.364 & 10000 \\
\hline 4 & 0.000 & 16.667 & 10000 \\
\hline 5 & 0.000 & 9.729 & 10000 \\
\hline 6 & 0.000 & 4.286 & 10000 \\
\hline 7 & 0.298 & 3.313 & 13.699 \\
\hline 8 & -1.358 & 0.911 & 10000 \\
\hline 9 & 0.000 & 0.3 & 10000 \\
\hline 10 & 0.000 & 0.089 & 10000 \\
\hline 11 & 0.000 & 0.025 & 10000 \\
\hline 12 & 0.000 & 0.000 & \\
\hline
\end{tabular}

Overall, the generalized ridge regressions identified a common factor affecting FDI net inflows in the V4 countries: perceived corruption index. Total tax rate is common for three countries (Poland, Hungary and Slovak Republic). In Poland, Czech Republic and Slovakia, the perceived corruption negatively affected the FDI, will in Hungary the level of corruption did not discourage the foreign investors. Even if corruption is a big risk for business environment and Hungary is classified by Transparency International among the most corrupted countries in the CEE region, aspects related to standard of life and exports seem to be more important for foreign investors when deciding to come in Hungary. For Hungary, Czech Republic and Slovakia, there are some common factors affecting FDI that are related to human resources quality: youth unemployment rate and labor force with advanced education.

These variables will be considered in the panel analysis. Granger causality in panel was tested on stationary data (Table 9). 
Table 9. Granger causality test for FDI and other variables in V4 countries (2005-2016) (source: own results)

\begin{tabular}{|l|c|c|}
\hline \multicolumn{1}{|c|}{ Cause $\rightarrow$ Effect } & F- statistic & Prob. \\
\hline Youth unemployment variation $\rightarrow$ FDI & 0.5699 & 0.5722 \\
\hline FDI $\rightarrow$ Youth unemployment variation & 1.8819 & 0.1717 \\
\hline Corruption index variation $\rightarrow$ FDI & 1.4127 & 0.2609 \\
\hline FDI $\rightarrow$ corruption index variation & 2.3863 & 0.1111 \\
\hline Total tax rate $\rightarrow$ FDI & 1.6646 & 0.2057 \\
\hline FDI $\rightarrow$ total tax rate & 3.3989 & 0.0463 \\
\hline Change in Labour force with advanced education $\rightarrow$ FDI & 0.4863 & 0.6201 \\
\hline FDI $\rightarrow$ Change in Labour force with advanced education & 0.0261 & 0.9742 \\
\hline
\end{tabular}

According to Granger causality test, the changes in youth unemployment rate and labour force with advanced studies as well as total tax rate and corruption index were not causes for FDI. However, the FDI attraction in V4 countries generated changes in corruption index and total tax rate at $10 \%$ level of significance.

A panel ARDL model was estimated for V4 countries (Table 10). The PMG estimator is used to restrict the long- term coefficients to have the same value across countries and only the short-term coefficients may change.

Table 10. Panel ARDL model to explain FDI in V4 countries (2005-2016) (source: own results)

\begin{tabular}{|l|c|c|c|}
\hline \multicolumn{1}{|c|}{ Error correction term } & Coefficient & $\mathrm{Z}$ & Prob. \\
\hline Corruption index in previous year & -0.1694 & -5.2 & 0.000 \\
\hline Labour forced with advanced education in previous year & 0.9291 & 10.99 & 0.000 \\
\hline Short-run & & & \\
\hline ECT & -1.2189 & -4.43 & 0.000 \\
\hline Corruption index in first difference & 0.0871 & 0.51 & 0.607 \\
\hline Labour forced with advanced education in first difference & -1.1382 & -1.21 & 0.224 \\
\hline
\end{tabular}

The results based on panel ARDL model indicated that there is a significant relationship between FDI, corruption index and Labour forced with advanced education in V4 countries only on long-run. The relation is not significant on short-run at $5 \%$ level of significance. So, the foreign investors are interested in corruption and the quality of labour resources as tendency on a longer period and they are not so sensitive to sudden changes from a year to another.

Given the particular position of FDI inflows in Hungary compared to the other countries, a separate analysis in panel will be provided for Poland, Slovakia and Czech Republic.

The Granger causality on panel data was checked (Table 11) for three countries (Poland, Czech Republic and Slovakia) because Hungary FDI behaved as an outlier. 
Table 11. Granger causality test for FDI and other variables in Poland, Czech Republic and Slovakia (2005-2016) (source: own results)

\begin{tabular}{|l|c|c|}
\hline \multicolumn{1}{|c|}{ Cause $\rightarrow$ Effect } & F- statistic & Prob. \\
\hline Youth unemployment variation $\rightarrow$ FDI & 0.4138 & 0.6669 \\
\hline FDI $\rightarrow$ Youth unemployment variation & 1.7759 & 0.1963 \\
\hline Corruption index variation $\rightarrow$ FDI & 1.8232 & 0.1886 \\
\hline FDI $\rightarrow$ corruption index variation & 2.4078 & 0.1169 \\
\hline Total tax rate $\rightarrow$ FDI & 1.4198 & 0.2630 \\
\hline FDI $\rightarrow$ total tax rate & 4.6916 & 0.0201 \\
\hline Change in Labour force with advanced education $\rightarrow$ FDI & 0.8518 & 0.4423 \\
\hline FDI $\rightarrow$ Change in Labour force with advanced education & 0.1358 & 0.8738 \\
\hline
\end{tabular}

The results are almost similar with those for V4 countries. According to Granger causality test, the changes in youth unemployment rate and labour force with advanced studies as well as total tax rate and corruption index were not causes for FDI. However, the FDI attraction in the three countries generated changes only in total tax rate at $5 \%$ level of significance, but the issues related to corruption were not changed, as expected from the previous results. One can conclude that Poland, Czech Republic and Slovakia are more sensitive to corruption compared to Hungary.

Table 12. Panel ARDL model to explain FDI in Poland, Czech Republic and Slovakia (2005-2016) (source: own results)

\begin{tabular}{|l|c|c|c|}
\hline \multicolumn{1}{|c|}{ Error correction term } & Coefficient & $\mathrm{z}$ & Prob. \\
\hline Corruption index in previous year & -0.1697 & -5.21 & 0.000 \\
\hline Labour forced with advanced education in previous year & 0.9293 & 10.99 & 0.000 \\
\hline Short-run & & & \\
\hline ECT & -1.4419 & -6.34 & 0.000 \\
\hline Corruption index in first difference & -0.04465 & -0.30 & 0.765 \\
\hline Labour forced with advanced education in first difference & -0.3163 & -0.5 & 0.619 \\
\hline Constant & 86.6476 & 7.36 & 0.000 \\
\hline
\end{tabular}

The results based on panel ARDL model (Table 12) are similar to those obtained for V4 countries. There is a significant relationship between FDI, corruption index and Labour forced with advanced education in Poland, Czech Republic and Slovakia only on long-run. The relation is not significant on short-run at $5 \%$ level of significance.

\section{Conclusions and discussions}

In this paper, an individual and panel analysis were conducted in order to identify the factors that affect FDI in V4 countries. In the study, we chose V4 countries as they are new EU member states from 2004, being among the most industrialized economies among recent 
EU members. The new economic realities after 2004 (EU integration and world economic crisis) made V4 one of the region that attracted most of the FDI from EU-15, but significant decreases were observed in crisis period. All these countries make effort to attract more FDI inflows from EU-15 and other states (different incentives for FDI and plans established by Government) due to positive effects of FDI for economy (economic growth, jobs creation, higher salaries, productive sector expansion, innovation in production techniques etc.). However, Brincikova and Darmo (2014) did not find evidence for a positive impact of FDI on employment and, therefore, new efforts should be made to attract FDI that ensure a sustainable development in the host country. From this perspective, we considered necessary to identify the factors with a significant impact on FDI in V4 countries in order to focus the actions in precise key points. The efforts should follow two directions: improvement in strong points that attract FDI inflows in V4 region and minimization of negative points as corruption that the foreign investors.

The empirical results based on individual analysis showed that perceived corruption is a common factor that affects FDI inflows in V4 countries. In Poland, Czech Republic and Slovakia corruption was a serious brake for FDI since 2005. Even if Hungary is perceived as a country with high influence, the foreign investors do not care about this, being more interested in the quality of human resources and the possibility to export more. The panel approach based on a panel ARDL model identified a significant relationship between FDI, corruption index and Labour forced with advanced education but only on long-run, the foreign investors following corruption and the quality of human resources only as tendency in these countries. On the other hand, the Granger causality in panel was checked and the attraction of FDI inflows succeeded in generating changes in total tax rate, but the issues related to corruption were not reduced at an acceptable level for foreign investors in Poland, Slovakia and Czech Republic.

Our empirical study is limited by the short period of analysis (2005-2016) based on the data availability and conditioned by the EU membership. However, in a follow-up study a comparative analysis of FDI determinants before and after the entrance in the EU should be conducted and it would constitute an interesting pathway for further research. Therefore, novel strategies intended for attracting FDI designed by the governments and governmental agencies should take into account more effective measures to reduce corruption in Poland, Slovakia and Czech Republic. In Hungary, the measures to reduce poverty are welcome together with the improvement of human resources quality.

\section{Acknowledgements}

This work was supported by the Philosophy and Social Science of Zhejiang Province (No. 17NDJC211YB), National Natural Science of China (No. 71671165) and First Class Discipline of Zhejiang - A (Zhejiang Gongshang University - Statistics). 


\section{References}

Abrhám, J., Strielkowski, W., Vošta, M., \& Šlajs, J. (2015a). Factors that influence the competitiveness of Czech rural small and medium enterprises. Agricultural Economics-Zemedelska Ekonomika, 61(10), 450-460. https://doi.org/10.17221/63/2015-AGRICECON

Abrhám, J., Bilan, Y., Krauchenia, A., \& Strielkowski, W. (2015b). Planning horizon in labour supply of Belarusian small entrepreneurs. Economic Research-Ekonomska Istraživanja, 28(1), 773-787. https://doi.org/10.1080/1331677X.2015.1084238

Aleksandruk, P., \& Forte, R. (2016). Location determinants of Portuguese FDI in Poland, Baltic Journal of European Studies, 6(2), 160-183.

Amarandei, C. M. (2013). Corruption and foreign direct investment. Evidence from Central and Eastern European States. CES Working Papers, 5(3), 311-322.

Avioutskii, V., \& Tensaout, M. (2016). Does politics matter? Partisan FDI in Central and Eastern Europe. Multinational Business Review, 24(4), 375-398. https://doi.org/10.1108/MBR-07-2015-0028

Bellos, S., \& Subasat, T. (2012). Corruption and foreign direct investment: a panel gravity model approach. Bulletin of Economic Research, 64(4), 565-574. https://doi.org/10.1111/j.1467-8586.2010.00370.x

Bevan, A. A., \& Estrin, S. (2004). The determinants of foreign direct investment into European transition economies. Journal of comparative economics, 32(4), 775-787. https://doi.org/10.1016/j.jce.2004.08.006

Boateng, A., Hua, X., Nisar, S., \& Wu, J. (2015). Examining the determinants of inward FDI: evidence from Norway. Economic Modelling, 47, 118-127. https://doi.org/10.1016/j.econmod.2015.02.018

Botrić, V., \& Škuflić, L. (2006). Main determinants of foreign direct investment in the southeast European countries. Transition Studies Review, 13(2), 359-377. https://doi.org/10.1007/s11300-006-0110-3

Brada, J. C., Kutan, A. M., \& Yigit, T. M. (2006). The effects of transition and political instability on foreign direct investment inflows, Economics of Transition, 14(4), 649-680. https://doi.org/10.1111/j.1468-0351.2006.00272.x

Brincikova, Z., \& Darmo, L. (2014). The impact of FDI inflow on employment in V4 countries. European Scientific Journal, 1, 245-252.

Castro, C., \& Nunes, P. (2013). Does corruption inhibit foreign direct investment. Política. Revista de Ciencia Política, 51(1), 61-83. https://doi.org/10.5354/0716-1077.2013.27418

Caves, R. E. (1996). Multinational enterprise and economic analysis. Cambridge: Cambridge University Press.

Chen, J. D., Cheng, S. L., Nikic, V., \& Song, M. L. (2018). Quo Vadis? Major players in global coal consumption and emissions reduction. Transformations in Business \& Economics, 17(1), 112-132.

Chidlow, A., Salciuviene, L., \& Young, S. (2009). Regional determinants of inward FDI distribution in Poland. International Business Review, 18(2), 119-133. https://doi.org/10.1016/j.ibusrev.2009.02.004

Cieślik, A. (2007). Augmented gravity equation and incomplete specialization in production. International Economics Letters, 4(1), 26-34.

Cieślik, A., Michałek, J. J., \& Mycielski, J. (2016). Globalization, international trade, and human development: a case of Central and Eastern Europe. Czech Journal of Social Sciences, Business and Economics, 5(2), 6-15.

Čábelková, I., Abrhám, J., \& Strielkowski, W. (2015). Factors influencing job satisfaction in post-transition economies: the case of the Czech Republic. International Journal of Occupational Safety and Ergonomics, 21(4), 448-456. https://doi.org/10.1080/10803548.2015.1073007

Demekas, D., Horvath, B., Ribakova, E., \& Wu, Y. (2005). Foreign direct investment in Southeastern Europe: how (and how much) can policies help? (IMF Working Paper No. 110). Washington DC: International Monetary Fund. 
Dumitrescu, E. I., \& Hurlin, C. (2012). Testing for Granger non-causality in heterogeneous panels. Economic Modelling, 29(4), 1450-1460. https://doi.org/10.1016/j.econmod.2012.02.014

Dunning, J. H. (1980). Toward an eclectic theory of international production: some empirical tests. Journal of International Business Studies, 11(1), 9-31. https://doi.org/10.1057/palgrave.jibs.8490593

Fernando, C. K., Hosseini, M. R., Zavadskas, E. K., Perera, B. A. K. S., \& Rameezdeen, R. (2017). Managing the financial risks affecting construction contractors: implementing hedging in Sri Lanka. International Journal of Strategic Property Management, 21(2), 212-224. https://doi.org/10.3846/1648715X.2017.1301592

Ghorabaee, M. K., Amiri, M., Zavadskas, E. K., Hooshmand, R., \& Antuchevičienè, J. (2017). Fuzzy extension of the CODAS method for multi-criteria market segment evaluation. Journal of Business Economics and Management, 18(1), 1-19. https://doi.org/10.3846/16111699.2016.1278559

Gorynia, M., Nowak, J., Howak, J., \& Wolniak, R. (2007). Motives and modes of FDI in Poland: an exploratory qualitative study. Journal for East European Management Studies, 12(2), 132-151. https://doi.org/10.5771/0949-6181-2007-2-132

Grančay, M., \& Grančay, N. (2017). Foreign Direct Investment in Slovakia: the Tatra tiger gone tame? In Foreign Direct Investment in Central and Eastern Europe (pp. 77-98). Springer International Publishing. https://doi.org/10.1007/978-3-319-40496-7_4

Guagliano, C., \& Riela, S. (2005). Do special economic areas matter in attracting FDI? Evidence from Poland, Hungary and Czech Republic. (ISLA Working paper). Milan: Centre for Research on Latin American Studies and Transition Economies, Bocconi University.

Günther, J., \& Kristalova, M. (2016). No risk, no fun? Foreign direct investment in Central and Eastern Europe. Intereconomics, 51(2), 95-99. https://doi.org/10.1007/s10272-016-0583-1

Hajiagha, S. H. R., Mahdiraji, H. A., Hashemi, S. S., \& Zavadskas, E. K. (2015). Evolving a linear programming technique for MAGDM problems with interval valued intuitionistic fuzzy information. Expert Systems with Applications, 42(23), 9318-9325. https://doi.org/10.1016/j.eswa.2015.07.067

Hashemkhani Zolfani, S., Maknoon, R., \& Zavadskas, E. K. (2016). An introduction to prospective multiple attribute decision making (PMADM). Technological and Economic Development of Economy, 22(2), 309-326. https://doi.org/10.3846/20294913.2016.1150363

Hlavacek, P., \& Bal-Domanska, B. (2016). Impact of foreign direct investment on economic growth in Central and Eastern European countries. Engineering Economics, 27(3), 294-303. https://doi.org/10.5755/j01.ee.27.3.3914

Hymer, S. H. (1976). The international operations of national firms: a study of direct foreign investment. Cambridge, MA: MLT Press.

Isard, W. (1954). Location theory and trade theory: short-run analysis. The Quarterly Journal of Economics, 68(2), 305-320. https://doi.org/10.2307/1884452

Janicki, H. P., \& Wunnava, P. V. (2004). Determinants of foreign direct investment: empirical evidence from EU accession candidates. Applied Economics, 36(5), 505-509. https://doi.org/10.1080/00036840410001682214

Jimborean, R., \& Kelber, A. (2017). Foreign direct investment drivers and growth in Central and Eastern Europe in the aftermath of the 2007 global financial crisis. Comparative Economic Studies, 59(1), 23-54. https://doi.org/10.1057/s41294-016-0018-9

Karabatsos, G. (2014). Fast marginal likelihood estimation of the Ridge parameter (s) in Ridge regression and generalized ridge regression for Big Data. arXiv preprint arXiv:1409.2437.

Kilic, C., Bayar, Y., \& Arica, F. (2014). Effects of currency unions on foreign direct investment inflows: the European economic and monetary union case. International Journal of Economics and Financial Issues, 4(1), 8-15. 
Lindley, D. V., \& Smith, A. F. (1972). Bayes estimates for the linear model. Journal of the Royal Statistical Society. Series B (Methodological), 34(1), 1-41.

Merlevede, B., \& Schoors, K. (2009). Privatisation and foreign direct investment in 10 transition countries. Post-communist economies, 21(2), 143-156. https://doi.org/10.1080/14631370902778450

Michalíkova, E., \& Galeotti, E. (2010). Determinants of FDI in Czech manufacturing industries between 2000-2007. South East European Journal of Economics and Business, 5(2), 21-32. https://doi.org/10.2478/v10033-010-0012-5

Nazarczuk, J. M., \& Krajewska, A. (2017, June). Local determinants of foreign direct investment in Poland (No. 84/2017). Paper presented at The $9^{\text {th }}$ International Conference on Applied Economics Contemporary Issues in Economy. Institute of Economic Research, Polish Economic Society Branch in Toruń, Faculty of Economic Sciences and Management, Nicolaus Copernicus University, Torun, Poland.

Pesaran, M. H., Shin, Y., \& Smith, R. P. (1999). Pooled mean group estimation of dynamic heterogeneous panels. Journal of the American Statistical Association, 94(446), 621-634.

https://doi.org/10.1080/01621459.1999.10474156

Porter, M. E. (1990). The competitive advantage of nations. Hampshire-London: MacMillan Press. https://doi.org/10.1007/978-1-349-11336-1

Qi, S. Z., \& Li, Y. (2017). Threshold effects of renewable energy consumption on economic growth under energy transformation. Chinese Journal of Population, Resources and Environment, 15(4), 312-321. https://doi.org/10.1080/10042857.2017.1416049

Resmini, L. (2000). The determinants of foreign direct investment in the CEECs: new evidence from sectoral patterns. Economics of Transition, 8(3), 665-689. https://doi.org/10.1111/1468-0351.00060

Rostamzadeh, R., Esmaeili, A., Nia, A. S., Saparauskas, J., \& Ghorabaee, M. K. (2017). A fuzzy aras method for supply chain management performance measurement in SMEs under uncertainty. Transformations in Business \& Economics, 16(2A), 319-348.

Sakali, C. (2013). Determinants of Foreign Direct Investment (FDI) in Bulgaria: an econometric analysis using panel data. Journal of Economics and Business, 16(1), 73-97.

Shepotylo, O. (2012). Spatial complementarity of FDI: the example of transition countries. Post-Communist Economies, 24(3), 327-349. https://doi.org/10.1080/14631377.2012.705468

Smarzynska, B. K., \& Wei, S. J. (2000). Corruption and composition of foreign direct investment: firmlevel evidence (No. w7969). National Bureau of Economic Research. https://doi.org/10.3386/w7969

Song, M. L., Fisher, R., Wang, J. L., \& Cui, L. B. (2018a). Environmental performance evaluation with big data: theories and methods. Annals of Operations Research, 1-14.

Song, M. L., Peng, J., Wang, J. L., \& Dong, L. (2018b). Better resource management: an improved resource and environmental efficiency evaluation approach that considers undesirable outputs. Resources, Conservation \& Recycling, 128, 197-205. https://doi.org/10.1016/j.resconrec.2016.08.015

Song, M. L., \& Wang, S. H. (2018). Market competition, green technology progress and comparative advantages in China. Management Decision, 56(1), 188-203.

https://doi.org/10.1108/MD-04-2017-0375

Stack, M. M., Ravishankar, G., \& Pentecost, E. (2017). Foreign direct investment in the Eastern European countries: determinants and performance. Structural Change and Economic Dynamics, 41, 86-97. https://doi.org/10.1016/j.strueco.2017.04.005

Stanujkic, D., \& Zavadskas, E. K. (2015). A modified weighted sum method based on the decisionmaker's preferred levels of performances. Studies in Informatics and Control, 24(4), 461-470. https://doi.org/10.24846/v24i4y201510

Subasat, T., \& Bellos, S. (2013). Governance and foreign direct investment in Latin America: a panel gravity model approach. Latin American Journal of Economics, 50(1), 107-131.

https://doi.org/10.7764/LAJE.50.1.107 
Wach, K., \& Wojciechowski, L. (2016). Determinants of inward FDI into Visegrad countries: empirical evidence based on panel data for the years 2000-2012. Economics and Business Review, 2(1), 34-52. https://doi.org/10.18559/ebr.2016.1.3

Walkenhorst, P. (2001). Determinants of foreign direct investment in the food industry: the case of Poland. Agribusiness, 17(3), 383-395. https://doi.org/10.1002/agr.1023

Wilhelms, S. K., \& Witter, M. S. D. (1998). Foreign direct investment and its determinants in emerging economies. Washington DC: United States Agency for International Development, Bureau for Africa, Office of Sustainable Development.

World Bank. (2017). Doing Business 2017. Equal opportunity for all (World Bank group flagship report). New York: The World Bank Publishing.

Zeng, S. Z. (2017). Pythagorean fuzzy multiattribute group decision making with probabilistic information and OWA approach. International Journal of Intelligent Systems, 32(11), 1136-1150. https://doi.org/10.1002/int.21886

Zeng, S. Z., Mu, Z. M., \& Balezentis, T. (2018). A novel aggregation method for Pythagorean fuzzy multiple attribute group decision making. International Journal of Intelligent Systems, 33(3), 573585. https://doi.org/10.1002/int.21953

Zeng, S. Z., Streimikiene, D., \& Baležentis, T. (2017). Review of and comparative assessment of energy security in Baltic States. Renewable and Sustainable Energy Reviews, 76, 185-192. https://doi.org/10.1016/j.rser.2017.03.037

Zhou, J., Su, W., Baležentis, T., \& Streimikiene, D. (2018). Multiple criteria group decision-making considering symmetry with regards to the positive and negative ideal solutions via the Pythagorean Normal Cloud Model for application to economic decisions. Symmetry, 10, 140.

https://doi.org/10.3390/sym10050140 